\title{
Oxidation of a 4-substituted chiral oxazoline using MCPBA and $\mathrm{NO}_{2}$
}

\author{
R. Alan Aitken* and David P. Armstrong \\ School of Chemistry, University of St Andrews, North Haugh, \\ St Andrews, Fife, KY16 9ST, UK \\ E-mail: raa@st-and.ac.uk
}

Dedicated to Gurnos Jones on the occasion of his $70^{\text {th }}$ birthday

(received 10 Feb 00; accepted 20 Aug 00; published on the web 28 Aug 00)

\begin{abstract}
Oxidation of the chiral oxazoline 1 using 1.6 equivalents of MCPBA gives mainly the corresponding ring-opened nitroso compound 4 isolated as its dimer 5 together with an E/Z mixture of the isomeric oximes 2 and 3. Upon treatment of 1 with an excess of $\mathrm{NO}_{2}$ the product is the alkyl nitrate 23 .
\end{abstract}

Keywords: Oxazolines, oxidation, MCPBA, ring-opening

\section{Introduction}

Some time ago we described the oxidation of a range of chiral 2-thiazolines (4,5dihydrothiazoles) which was found to result in either $S$-oxidation to give thiazoline $S, S$-dioxides which were subject to subsequent hydrolytic ring-opening and disproportionation or else dehydrogenation to give thiazoles depending on the conditions used. ${ }^{1}$ In no case was $N$-oxidation observed. On the other hand, 2-oxazolines (4,5-dihydrooxazoles) are known to undergo oxidation to the corresponding oxaziridines with MCPBA and these may be isomerised to the corresponding oxazoline $N$-oxides on silica gel. ${ }^{2}$ The 4,4-dimethyloxazoline $N$-oxides formed in this way or by an alternative ring synthesis have been shown to be effective 1,3-dipoles. ${ }^{3}$ Since we had available a range of chiral 4-substituted oxazolines used as precursors for the corresponding thiazolines, ${ }^{1}$ we decided to examine oxidation of these in the hope that the $N$ oxides might prove to be useful chiral 1,3-dipoles for asymmetric synthesis. In this paper the results of oxidation of the representative oxazoline 1 with both MCPBA and the more unusual oxidant $\mathrm{NO}_{2}$ are described. 


\section{Results and Discusion}

When a solution of the chiral oxazoline 1 in $\mathrm{CH}_{2} \mathrm{Cl}_{2}$ was treated with MCPBA (1.6 equiv.) at RT a deep blue-green colour developed which slowly faded. Work-up and chromatographic separation of the products gave, as minor products, the $Z$ and $E$ oximes 2 and 3 and as the major product the dimer 5 of the nitroso compound 4. The formation of dimers of this type from aliphatic nitroso compounds is well known, ${ }^{4}$ and the yellow dimer 5 was found to dissociate to 4 in boiling toluene as indicated by formation of an intense blue colour which reverted to yellow upon cooling. Both attempted distillation and prolonged storage of 5 led to complete conversion into a mixture of 2 and 3 suggesting that these are the most thermodynamically stable isomers in this system. The formation of 5 would not be expected to result in racemisation and indeed it showed a substantial optical rotation although its enantiomeric purity was not readily confirmed.
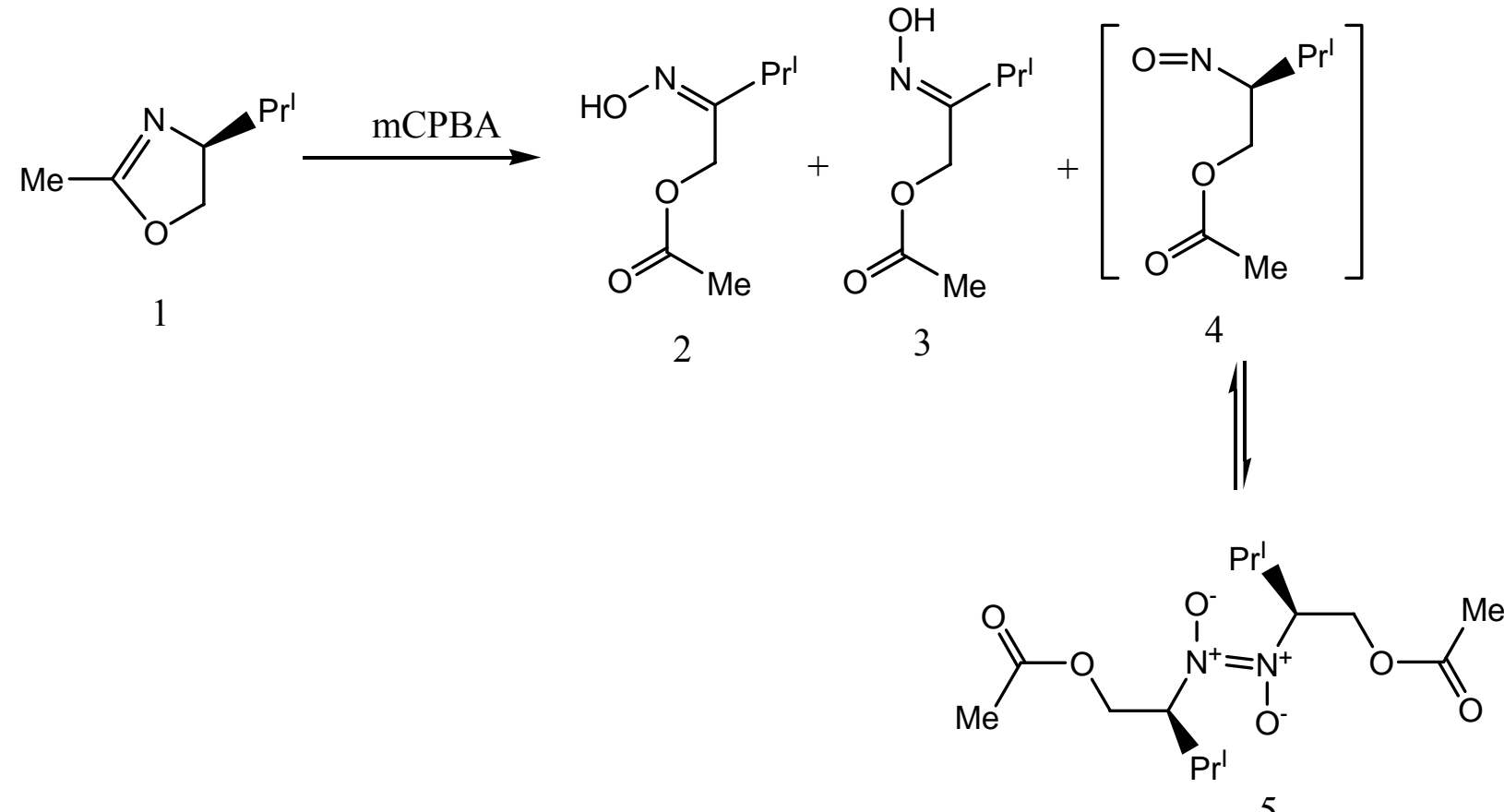

It is of interest to compare our results with those found previously for the 4,4-disubstituted compounds 6 and the 4-unsubstituted compound 12. In the case of $6(\mathrm{R}=\mathrm{n}$-pentyl) reaction with MCPBA (1 equiv.) gave the oxaziridine 7 which was isomerised by silica gel to the oxazoline $N$ oxide 8 . This could be hydrolysed to the hydroxylamine 9 which was then oxidised by MCPBA ( 1 equiv.) to the nitroso compound 10. In contrast to 4 this showed no tendency to dimerise presumably due to steric hindrance. ${ }^{2}$ On the other hand, treatment of 6 with an excess of MCPBA led directly to the nitro compound 11 which could be reduced to 9 using zinc and ammonium chloride. 

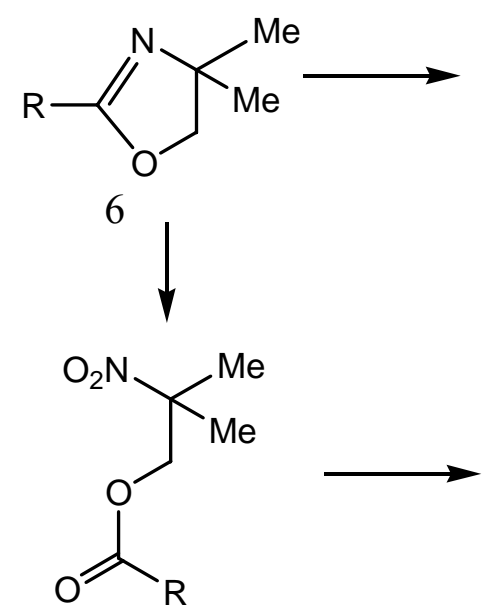
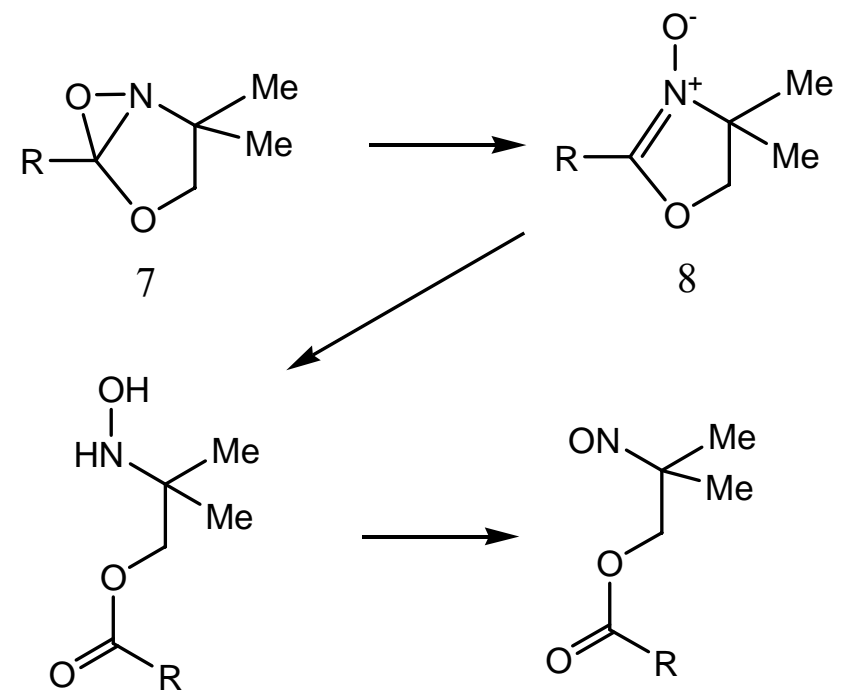

9

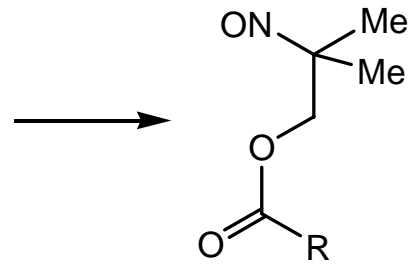

10

For the 4-unsubstituted compound 12, oxidation with MCPBA (1 equiv.) gave only partial oxidation to the oxaziridine 13 and it was found to be impossible to achieve complete reaction without further oxidation via 16 to give the ring-opened nitroso compound 17 which existed entirely as a mixture of the isomeric oximes $18 .^{5}$ When 13 was heated in solution it underwent ring-opening to give the cyclic trimer 15 of the imine 14 .

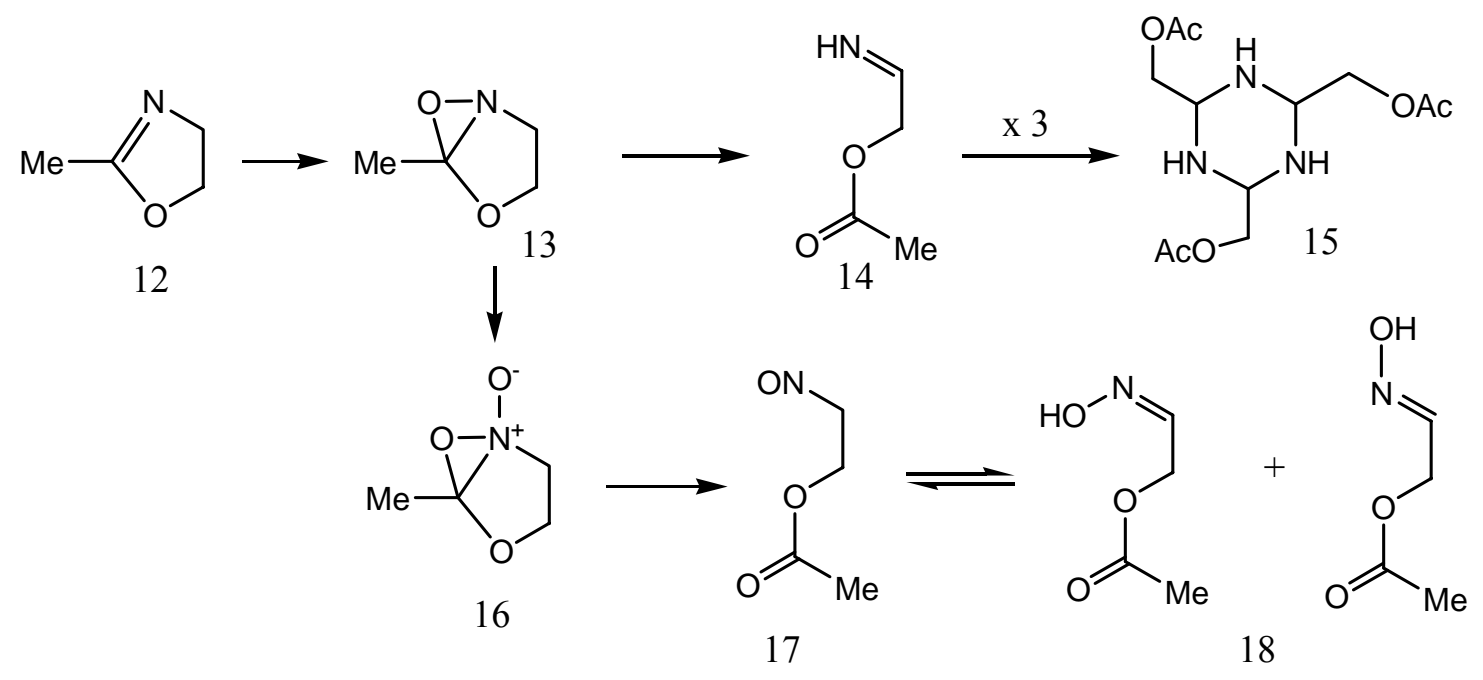

Langlois and coworkers have recently examined the synthetic utility of chiral oxazoline $N$ oxides. Although both the 4,4-dimethyl compounds 19 and the ephedrine-derived chiral compounds 20 could be oxidised to the corresponding oxaziridines, isomerisation of these to the $\mathrm{N}$-oxides on silica was accompanied by a significant degree of hydrolysis to give the acyloxy hydroxylamines corresponding to 9 and the $N$-oxides were used for cycloaddition in impure form. ${ }^{6}$ In all later work, the camphor-derived compounds 22 have been formed directly by 
treatment of 21 with an ortho ester rather than by $N$-oxidation. ${ }^{7}$ The $N$-oxide of $20(\mathrm{R}=\mathrm{Me})$ has also been prepared by oxygen transfer from a dihydroisoquinoline-derived oxaziridinium salt followed by acid-mediated isomerisation. ${ }^{8}$

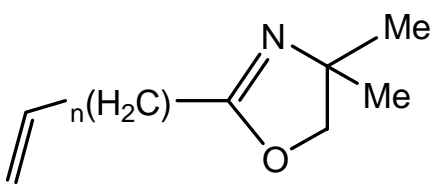

19

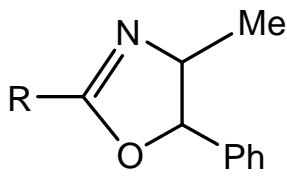

20

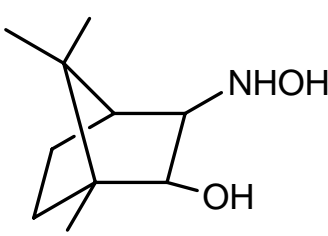

21

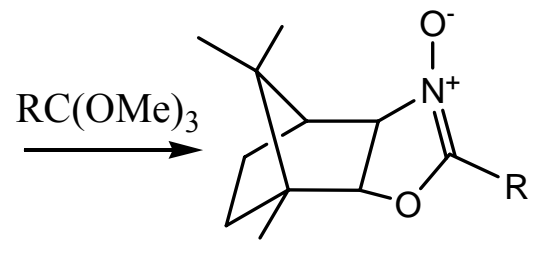

22

It appears therefore that the oxazoline 1 is more similar to the 4-unsubstituted compound 12 in its behaviour with MCPBA in that reaction cannot be stopped at the monooxidation stage and ring-opening ensues. It is notable however that the nitroso dimer 5 is obtained as the major product in our case whereas 17 was not detected and immediately isomerised to the oximes 18 . It might also be noted that similar ring-opening behaviour is observed for 2-alkylpyrroline $\mathrm{N}$ oxides. ${ }^{9}$

Nitrogen dioxide is a rather interesting oxidant which has recently been used for a variety of systems such as 1,2,5-thiadiazoles ${ }^{10}$ and phosphorus ylides. ${ }^{11}$ Treatment of the oxazoline 1 with an excess of $\mathrm{NO}_{2}$ in $\mathrm{CH}_{2} \mathrm{Cl}_{2}$ at $\mathrm{RT}$ led to formation of a green colour and, after evaporation and chromatographic purification, a product was isolated which appeared to be the ring-opened alkyl nitrate 23. It is not clear whether the nitrate ester function is derived from oxidation of the nitrite formed by rearrangement of the nitro compound similar to 11 or whether it has come from the $\mathrm{NO}_{2}$. In view of the potentially explosive nature of this compound it was not investigated further.

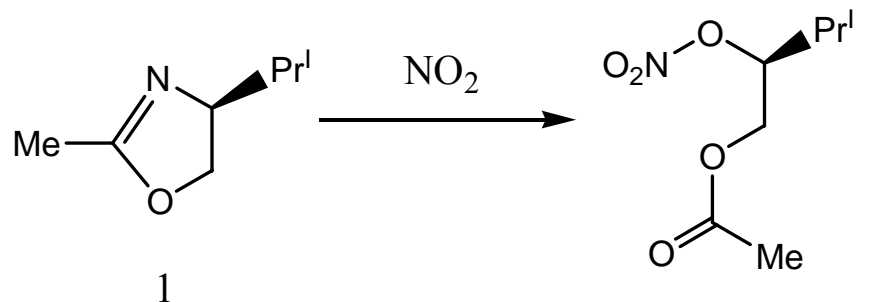

23

In conclusion, it appears that in moving from 4,4-disubstituted oxazolines to the 4monosubstituted chiral analogues, the oxidation behaviour becomes considerably more complex with the result that it is no longer a simple matter to obtain the oxazoline $\mathrm{N}$-oxides of interest as chiral 1,3-dipoles. 


\section{Experimental Section}

General Procedures. Infra red spectra were recorded as thin films on a Perkin Elmer 1420 instrument. NMR spectra were obtained for ${ }^{1} \mathrm{H}$ at $80 \mathrm{MHz}$ using a Bruker WP80 instrument and for ${ }^{13} \mathrm{C}$ at $75 \mathrm{MHz}$ using a Bruker $\mathrm{AM} 300$ instrument. All spectra were run on solutions in $\mathrm{CDCl}_{3}$ with internal $\mathrm{Me}_{4} \mathrm{Si}$ as reference. Chemical shifts are reported in ppm to high frequency of the reference and coupling constants $J$ are in Hz. Mass spectra were obtained on an A. E. I. MS-902 spectrometer using electron impact at $70 \mathrm{eV}$. Optical rotations were determined on an Optical Activity AA1000 polarimeter and are given in units of $10^{-1} \mathrm{deg} \mathrm{cm}^{2} \mathrm{~g}^{-1}$.

The chiral oxazoline 1 was prepared as described previously. ${ }^{1}$

\section{Reaction of oxazoline 1 with MCPBA}

A solution of the oxazoline $1(4.2 \mathrm{~g}, 3.3 \mathrm{mmol})$ in $\mathrm{CH}_{2} \mathrm{Cl}_{2}\left(200 \mathrm{~cm}^{3}\right)$ was stirred at RT while a solution of $m$-chloroperbenzoic acid $(9.0 \mathrm{~g}, 5.2 \mathrm{mmol})$ in $\mathrm{CH}_{2} \mathrm{Cl}_{2}\left(150 \mathrm{~cm}^{3}\right)$ was added slowly. After stirring for 1-2 $\mathrm{h}$ a blue-green colour developed which subsequently faded. After $17 \mathrm{~h}$, the mixture was washed with saturated aqueous sodium carbonate $\left(6 \times 50 \mathrm{~cm}^{3}\right)$, dried and evaporated. Chromatography of the residue on silica eluting with hexane-diethyl ether (4:1) gave a (3:2) mixture of (Z)- and (E)-2-hydroxyimino-3-methyl-1-butyl acetate (2 and 3) (0.28 g, 5\%) as a colourless liquid. (Found: $\mathrm{C}, 53.0 ; \mathrm{H}, 8.5 ; \mathrm{N}, 8.8 . \mathrm{C}_{7} \mathrm{H}_{13} \mathrm{NO}_{3}$ requires $\mathrm{C}, 52.8 ; \mathrm{H}, 8.2 ; \mathrm{N}$, $8.8 \%) v_{\max } / \mathrm{cm}^{-1} 3700-2700(\mathrm{br}, \mathrm{OH}), 1750(\mathrm{C}=\mathrm{O}), 1650(\mathrm{C}=\mathrm{N}), 1565,1450,1370,1220,1050$, 950 and 750; $\mathrm{m} / \mathrm{z} 159$ (M, 3\%), 139 (2), 129 (2), 99 (62), 84 (9), 69 (96) and 43 (100).

(Z)-2-hydroxyimino-3-methyl-1-butyl acetate (2) $\delta_{\mathrm{H}} 10.2-9.5(1 \mathrm{H}, \mathrm{br} \mathrm{s}, \mathrm{OH}), 5.00(2 \mathrm{H}, \mathrm{s}$, $\left.\mathrm{CH}_{2} \mathrm{O}\right), 2.65\left(1 \mathrm{H}\right.$, septet, $J$ 8, $\left.\mathrm{CHMe}_{2}\right), 2.10\left(3 \mathrm{H}, \mathrm{s}, \mathrm{COCH}_{3}\right)$ and $1.13(6 \mathrm{H}, \mathrm{d}, J, \mathrm{Me}) ; \delta_{\mathrm{C}}$ $170.7(\mathrm{C}=\mathrm{O}), 160.4(\mathrm{C}=\mathrm{N}), 58.0\left(\mathrm{CH}_{2} \mathrm{O}\right), 30.6\left(\mathrm{COCH}_{3}\right), 20.8\left(\mathrm{CHMe}_{2}\right)$ and $19.9(2 \mathrm{Me})$.

(E)-2-hydroxyimino-3-methyl-1-butyl acetate (3) $\delta_{\mathrm{H}} 10.2-9.5(1 \mathrm{H}, \mathrm{br} \mathrm{s}, \mathrm{OH}), 4.70(2 \mathrm{H}, \mathrm{s}$, $\left.\mathrm{CH}_{2} \mathrm{O}\right), 3.40\left(1 \mathrm{H}\right.$, septet, $J$ 8, $\left.\mathrm{CHMe}_{2}\right), 2.08\left(3 \mathrm{H}, \mathrm{s}, \mathrm{COCH}_{3}\right)$ and $1.13(6 \mathrm{H}, \mathrm{d}, J \mathrm{r}, \mathrm{Me}) ; \delta_{\mathrm{C}}$ $170.6(\mathrm{C}=\mathrm{O}), 159.5(\mathrm{C}=\mathrm{N}), 62.3\left(\mathrm{CH}_{2} \mathrm{O}\right), 25.9\left(\mathrm{COCH}_{3}\right), 20.8\left(\mathrm{CHMe}_{2}\right)$ and $18.6(2 \mathrm{Me})$.

Further elution using hexane-diethyl ether (1:1) gave (E)-(2S)-2-azo-3-methylbut-1-yl acetate $N, N^{\prime}$-dioxide (5) (3.07 g, 58\%) as a yellow liquid. (HRMS: found $\mathrm{M}, 318.1803 . \mathrm{C}_{14} \mathrm{H}_{26} \mathrm{~N}_{2} \mathrm{O}_{6}$ requires $M, 318.1791)[\boldsymbol{\alpha}]-9.0\left(c 1.6, \mathrm{CHCl}_{3}\right) ; \lambda$ max $/ \mathrm{nm}(\mathrm{EtOH}) 292(\log \varepsilon 5.0)$ and $205(\log \boldsymbol{\varepsilon}$ $5.02) ; v_{\max } / \mathrm{cm}^{-1} 1750(\mathrm{C}=\mathrm{O}), 1470,1440,1380,1370,1230,1200,1130,1040$ and $840 ; \delta_{\mathrm{H}} 5.45$ $(2 \mathrm{H}, \mathrm{td}, J \mathrm{~B}, 4, \mathrm{CHN}), 4.58\left(2 \mathrm{H}\right.$, half $\mathrm{AB}$ pattern of d, $\left.J 12,4, \mathrm{CH}_{2} \mathrm{O}\right), 4.35(2 \mathrm{H}$, half $\mathrm{AB}$ pattern of d, $\left.J 12,8, \mathrm{CH}_{2} \mathrm{O}\right), 2.27(2 \mathrm{H}$, octet, $J$ 8, $\mathrm{CHMe} 2), 2.00\left(6 \mathrm{H}, \mathrm{s}, \mathrm{COCH}_{3}\right), 1.05(6 \mathrm{H}, \mathrm{d}, J$ 6, Me) and $0.95(6 \mathrm{H}, \mathrm{d}, J \mathrm{8}, \mathrm{Me}) ; \delta_{\mathrm{C}} 170.2(\mathrm{C}=\mathrm{O}), 70.7(\mathrm{CHN}), 61.6\left(\mathrm{CH}_{2} \mathrm{O}\right), 28.2\left(\mathrm{COCH}_{3}\right)$, $20.5\left(\mathrm{CHMe}_{2}\right), 19.5(\mathrm{Me})$ and $16.4(\mathrm{Me}) ; \mathrm{m} / \mathrm{z} 319$ (M, 5\%), 318 (M, 2), 298 (6), 228 (8), 184 (3), 160 (35), 139 (50), 129 (27), 118 (12), 100 (38), 90 (7) and 69 (100).

\section{Effect of heat upon dimer 5}

Attempted Kugelrohr distillation of $5(0.5 \mathrm{~g})$ gave a mixture of the (Z)- and (E)-oximes 2 and 3 (0.32 g), bp (oven temperature) $195^{\circ} \mathrm{C}$ at 0.9 Torr. 
Heating a solution of $5(0.20 \mathrm{~g})$ in toluene $\left(10 \mathrm{~cm}^{3}\right)$ under reflux led to rapid formation of the monomeric nitroso compound 4 as indicated by a change from yellow to blue but upon cooling the colour reverted to yellow.

Storage of 5 at RT for 3 months resulted in complete conversion into a mixture of the (Z)- and (E)-oximes 2 and 3.

\section{Reaction of oxazoline 1 with $\mathrm{NO}_{2}$}

A solution of the oxazoline $1(3.0 \mathrm{~g}, 23.6 \mathrm{mmol})$ in $\mathrm{CH}_{2} \mathrm{Cl}_{2}\left(50 \mathrm{~cm}^{3}\right)$ was stirred at $0{ }^{\circ} \mathrm{C}$ while a solution of $\mathrm{NO}_{2}(2.7 \mathrm{~g}, 60 \mathrm{mmol})$ in $\mathrm{CH}_{2} \mathrm{Cl}_{2}\left(50 \mathrm{~cm}^{3}\right)$ was added slowly. After the addition the mixture was stirred and allowed to warm to RT over $20 \mathrm{~h}$. Evaporation gave a pale green liquid. Chromatography of this on silica using petroleum-diethyl ether (2:1) gave (2S)-3-methyl-2nitrato-1-butyl acetate (23) (1.26 g, $28 \%$ ) as a pale yellow liquid, bp (oven temperature) $162{ }^{\circ} \mathrm{C}$ at 8 Torr. (HRMS: found $\mathrm{M} \mathrm{H}, 192.0856 . \mathrm{C}_{7} \mathrm{H}_{13} \mathrm{NO}_{5}$ requires $\left.M H, 192.0872\right) \delta_{\mathrm{H}} 5.25-4.95(1 \mathrm{H}$, $\mathrm{m}, \mathrm{CHO}), 4.40\left(1 \mathrm{H}\right.$, half $\mathrm{AB}$ pattern of d, $\left.J 12,3, \mathrm{CH}_{2} \mathrm{O}\right), 4.10(1 \mathrm{H}$, half AB pattern of $\mathrm{d}, J 12$, 8, $\left.\mathrm{CH}_{2} \mathrm{O}\right), 2.05\left(3 \mathrm{H}, \mathrm{s}, \mathrm{COCH}_{3}\right), 2.05\left(1 \mathrm{H}\right.$, octet, $J$ 8, $\left.\mathrm{CHMe}_{2}\right)$ and $1.04(6 \mathrm{H}, \mathrm{d}, J 8, \mathrm{Me}) ; \delta_{\mathrm{C}}$ $170.6(\mathrm{C}=\mathrm{O}), 85.4(\mathrm{CHO}), 62.4\left(\mathrm{CH}_{2} \mathrm{O}\right), 28.9\left(\mathrm{COCH}_{3}\right), 20.6\left(\mathrm{CHMe}_{2}\right), 18.4(\mathrm{Me})$ and 18.0 (Me); m/z 192 (M H, 25\%), 174 (35), 156 (10), 132 (12), 129 (53), 114 (34), 85 (43), 69 (62) and 43 (100).

\section{Acknowledgements}

We thank EPSRC and ICI Pharmaceuticals, Alderley Park (now AstraZeneca) for a CASE studentship (DPA).

\section{References}

1. Aitken, R. A.; Armstrong, D. P.; Galt, R. H. B.; Mesher, S. T. E. J. Chem. Soc., Perkin Trans. 1 1997, 935.

2. Keana, J. F. W.; Lee, T. D. J. Am. Chem. Soc. 1975, 97, 1273. (b) Lee, T. D.; Keana, J. F. W. J. Org. Chem. 1976, 41, 3237.

3. Ashburn, S. P.; Coates, R. M. J. Org. Chem. 1984, 49, 3127.(b) Ashburn, S. P.; Coates, R. M. J. Org. Chem. 1985, 50, 3076.

4. Emmons, W. D. J. Am. Chem. Soc. 1957, 79, 6522. (b) Beckett, A. H.; Jones, G. R.; Coutts, R. T. Tetrahedron 1976, 32, 1267.

5. Aue, D. H.; Thomas, D. J. Org. Chem. 1974, 39, 3855.

6. (a) Kobayakawa, M.; Langlois, Y. Tetrahedron Lett. 1992, 33, 2353. (b) Bérranger, T.; André-Barrès, C.; Kobayakawa, T.; Langlois, Y. Tetrahedron Lett. 1993, 34, 5079. 
7. (a) Dirat, O.; Berranger, T.; Langlois, Y. Synlett 1995, 935. (b) Berranger, T.; Langlois, Y. Tetrahedron Lett. 1995, 36, 5523. (c) Dalko, P. I.; Langlois, Y. Tetrahedron Lett. 1998, 39, 2107. (d) Kouklovsky, C.; Dirat, O.; Berranger, T.; Langlois, Y.; Tran-Huu-Dau, M. E.; Riche, C. J. Org. Chem. 1998, 63, 5123. (e) Dirat, O.; Kouklovsky, C.; Langlois, Y. J. Org. Chem. 1998, 63, 6634. (f) Dirat, O.; Kouklovsky, C.; Langlois, Y.; Lesot, P.; Courtieu, J. Tetrahedron: Asymmetry 1999, 10, 3197.

8. Hanquet, G.; Lusinchi, X. Tetrahedron 1994, 50, 12185.

9. Bapat, J. B.; Durie, A. Aust. J. Chem. 1984, 37, 211.

10. Dunn, P. J.; Rees, C. W.; Slawin, A. M. Z.; Williams, D. J. J. Chem. Soc., Chem. Commun. 1989, 1134.

11. Bestmann, H. J.; Kamberger, W.; Röder, T.; Zimmermann, R. Liebigs Ann. Chem. 1996, 845 (b) Aitken, R. A.; Karodia, N. Eur. J. Org. Chem. 1999, 251. 